\title{
Sixty years of radiocarbon dioxide measurements at Wellington, New Zealand: 1954-2014
}

\author{
Jocelyn C. Turnbull ${ }^{1,2}$, Sara E. Mikaloff Fletcher ${ }^{3}$, India Ansell ${ }^{1}$, Gordon W. Brailsford ${ }^{3}$, Rowena C. Moss ${ }^{3}$, \\ Margaret W. Norris ${ }^{1}$, and Kay Steinkamp ${ }^{3}$ \\ ${ }^{1}$ GNS Science, Rafter Radiocarbon Laboratory, Lower Hutt, New Zealand \\ ${ }^{2}$ CIRES, University of Colorado at Boulder, Boulder, Colorado, USA \\ ${ }^{3}$ National Institute of Water and Atmospheric Research (NIWA), Wellington, New Zealand
}

Correspondence: Jocelyn C. Turnbull (j.turnbull@gns.cri.nz)

Received: 9 December 2016 - Discussion started: 20 December 2016

Revised: 12 October 2017 - Accepted: 1 November 2017 - Published: 12 December 2017

\begin{abstract}
We present 60 years of $\Delta^{14} \mathrm{CO}_{2}$ measurements from Wellington, New Zealand $\left(41^{\circ} \mathrm{S}, 175^{\circ} \mathrm{E}\right)$. The record has been extended and fully revised. New measurements have been used to evaluate the existing record and to replace original measurements where warranted. This is the earliest direct atmospheric $\Delta^{14} \mathrm{CO}_{2}$ record and records the rise of the ${ }^{14} \mathrm{C}$ "bomb spike" and the subsequent decline in $\Delta^{14} \mathrm{CO}_{2}$ as bomb ${ }^{14} \mathrm{C}$ moved throughout the carbon cycle and increasing fossil fuel $\mathrm{CO}_{2}$ emissions further decreased atmospheric $\Delta^{14} \mathrm{CO}_{2}$. The initially large seasonal cycle in the 1960s reduces in amplitude and eventually reverses in phase, resulting in a small seasonal cycle of about $2 \%$ in the 2000s. The seasonal cycle at Wellington is dominated by the seasonality of cross-tropopause transport and differs slightly from that at Cape Grim, Australia, which is influenced by anthropogenic sources in winter. $\Delta^{14} \mathrm{CO}_{2}$ at Cape Grim and Wellington show very similar trends, with significant differences only during periods of known measurement uncertainty. In contrast, similar clean-air sites in the Northern Hemisphere show a higher and earlier bomb ${ }^{14} \mathrm{C}$ peak, consistent with a 1.4-year interhemispheric exchange time. From the 1970s until the early 2000s, the Northern and Southern Hemisphere $\Delta^{14} \mathrm{CO}_{2}$ were quite similar, apparently due to the balance of ${ }^{14} \mathrm{C}$-free fossil fuel $\mathrm{CO}_{2}$ emissions in the north and ${ }^{14} \mathrm{C}$-depleted ocean upwelling in the south. The Southern Hemisphere sites have shown a consistent and marked elevation above the Northern Hemisphere sites since the early 2000 s, which is most likely due to reduced upwelling of ${ }^{14} \mathrm{C}$ depleted and carbon-rich deep waters in the Southern Ocean, although an underestimate of fossil fuel $\mathrm{CO}_{2}$ emissions or
\end{abstract}

changes in biospheric exchange are also possible explanations. This developing $\Delta^{14} \mathrm{CO}_{2}$ interhemispheric gradient is consistent with recent studies that indicate a reinvigorated Southern Ocean carbon sink since the mid-2000s and suggests that the upwelling of deep waters plays an important role in this change.

\section{Introduction}

Measurements of radiocarbon in atmospheric carbon dioxide $\left(\Delta^{14} \mathrm{CO}_{2}\right)$ have long been used as a key to understanding the global carbon cycle. The first atmospheric $\Delta^{14} \mathrm{CO}_{2}$ measurements were begun at Wellington, New Zealand in 1954 (Rafter, 1955; Rafter and Fergusson, 1959), aiming to better understand carbon exchange processes (Otago Daily Times, 1957). Northern Hemisphere $\Delta^{14} \mathrm{CO}_{2}$ measurements began a few years later in 1962, in Norway (Nydal and Løvseth, 1983), and 1959, in Austria (Levin et al., 1985).

${ }^{14} \mathrm{C}$ is a cosmogenic nuclide produced naturally in the upper atmosphere through neutron spallation; it reacts rapidly to form ${ }^{14} \mathrm{CO}$ and then oxidizes to ${ }^{14} \mathrm{CO}_{2}$ over a period of 1-2 months, after which it moves throughout the global carbon cycle. Natural ${ }^{14} \mathrm{C}$ production is roughly balanced by radioactive decay, which mostly occurs in the carbon-rich and slowly overturning ocean carbon reservoir and to a lesser extent in the faster cycling terrestrial carbon reservoir. The perturbations to $\triangle^{14} \mathrm{CO}_{2}$ from atmospheric nuclear weapons testing in the mid-20th century and additions of ${ }^{14} \mathrm{C}$-free $\mathrm{CO}_{2}$ 
from fossil fuel burning have both provided tools to investigate $\mathrm{CO}_{2}$ sources and sinks.

The penetration of bomb- ${ }^{14} \mathrm{C}$ into the oceans has been used to understand ocean carbon uptake processes (Oeschger et al., 1975; Broecker et al., 1985; Key et al., 2004; Naegler et al., 2006; Sweeney et al., 2007). Terrestrial biosphere carbon residence times and exchange processes have also been widely investigated using bomb- ${ }^{14} \mathrm{C}$ (e.g. Trumbore, 2000; Naegler and Levin, 2009). Stratospheric residence times, cross-tropopause transport and interhemispheric exchange can also be examined with atmospheric $\Delta^{14} \mathrm{CO}_{2}$ observations (Kjellström et al., 2000; Kanu et al., 2015).

The Suess effect, the decrease in atmospheric $\Delta^{14} \mathrm{CO}_{2}$ due to the addition of ${ }^{14} \mathrm{C}$-free fossil fuel $\mathrm{CO}_{2}$, was first identified in 1955 (Suess, 1955). It has subsequently been refined (Meijer et al., 1996; Levin et al., 2003) and used to investigate fossil fuel $\mathrm{CO}_{2}$ additions on various scales (e.g. Turnbull et al., 2009a, 2015; Djuricin et al., 2010; Miller et al., 2012; Lopez et al., 2013).

The full atmospheric ${ }^{14} \mathrm{C}$ budget has been investigated using long-term $\Delta^{14} \mathrm{CO}_{2}$ records in conjunction with atmospheric transport models (Caldiera et al., 1998; Randerson et al., 2002; Naegler et al., 2006; Turnbull et al., 2009b; Levin et al., 2010). These have shown changing controls on $\Delta^{14} \mathrm{CO}_{2}$ through time. Prior to nuclear weapons testing, natural cosmogenic production added ${ }^{14} \mathrm{C}$ to the upper atmosphere, which reacted to $\mathrm{CO}_{2}$ and moved throughout the atmosphere and the carbon cycle. The short carbon residence time in the biosphere meant that biospheric exchange processes only had a small influence on $\Delta^{14} \mathrm{CO}_{2}$, whereas the ocean exerted a stronger influence due to radioactive decay during its much longer (and temporally varying) turnover time. The addition of bomb ${ }^{14} \mathrm{C}$ in the 1950 s and 1960 s almost doubled the atmospheric ${ }^{14} \mathrm{C}$ content. This meant that both the ocean and biosphere were very ${ }^{14} \mathrm{C}$-poor relative to the atmosphere in the two decades following the atmospheric test ban treaty. As the bomb- ${ }^{14} \mathrm{C}$ was distributed throughout the carbon cycle, this impact weakened, and by the 1990s, the additions of fossil fuel $\mathrm{CO}_{2}$ became the largest contributor to the $\Delta^{14} \mathrm{CO}_{2}$ trend (Randerson et al., 2002; Turnbull et al., 2007; Levin et al., 2010; Graven et al., 2012).

The long-term $\Delta^{14} \mathrm{CO}_{2}$ records have been crucial in all of these findings, and the Wellington $\Delta^{14} \mathrm{CO}_{2}$ record is of special importance, being the oldest direct atmospheric trace gas record, even predating the $\mathrm{CO}_{2}$ mole fraction record started at Mauna Loa in 1958 (Keeling, 1961; Keeling and Whorf, 2005). It is the only Southern Hemisphere record recording the bomb spike. Several short Southern Hemisphere records do exist (Manning et al., 1990; Meijer et al., 2006; Graven et al., 2012; Hua et al., 2013), and some longer records began in the 1980s (Levin et al., 2010). Over the more than 60 years of measurement, there have necessarily been changes in how the Wellington samples are collected and measured. There are no comparable records during the first 30 years of measurement, so that the data quality has not been indepen- dently evaluated. Comparison with other records since the mid-1980s has suggested that there may be biases in some parts of the Wellington record (Currie et al., 2011).

Here we present a revised and extended Wellington atmospheric ${ }^{14} \mathrm{CO}_{2}$ record, spanning 60 years from December 1954 to December 2014. We detail the different sampling, preparation and measurement techniques used through the record, compare it with new tree ring measurements, discuss revisions to the previously published data and provide a final dataset with an accompanying smooth curve fit.

In the results and discussion, we revisit the key findings that the Wellington ${ }^{14} \mathrm{CO}_{2}$ record has provided over the years and expand them with new findings based on the most recent part of the record. The most recent publication of this dataset included data to 2005 (Currie et al., 2011) and showed periods of variability and a seasonal cycle at Wellington that differ markedly from the independent Cape Grim, Tasmania, ${ }^{14} \mathrm{CO}_{2}$ record at a similar southern latitude (Levin et al., 2010). Here we add complementary new data to investigate these differences, fill gaps and extend the record to the nearpresent.

\section{Methods}

Over 60 years of measurement, a number of different sample collection, preparation, measurement and reporting methods have been used. In this section, we give an overview of the various methods and changes through time, and they are summarized in Table 1. Full details of the sampling methods used through time are provided in the Supplement, compiling methodological information documented in previous reports on the Wellington record (Rafter and Fergusson, 1959; Manning et al., 1990; Currie et al., 2011) along with methods newly applied in this new extension and refinement of the dataset.

\subsection{Sampling sites}

Samples from 15 December 1954 to 5 June 1987 were collected at Makara (Lowe, 1974), on the south-west coast of the North Island of New Zealand (MAK; $41.25^{\circ} \mathrm{S}, 174.69^{\circ} \mathrm{E}$; $300 \mathrm{~m}$ above sea level). Samples since 8 July 1988 have been collected at Baring Head (Brailsford et al., 2012) on the south coast of the lower North Island and $23 \mathrm{~km}$ south-east of Makara (BHD; $41.41^{\circ} \mathrm{S}, 174.87^{\circ} \mathrm{E} ; 80 \mathrm{~m}$ a.s.l.; Fig. 1). We also discuss tree ring samples collected from Eastbourne, $12 \mathrm{~km}$ north of Baring Head on Wellington Harbour.

\subsection{Collection methods}

\subsubsection{NaOH absorption}

The primary collection method is static absorption of $\mathrm{CO}_{2}$ into nominally $\mathrm{CO}_{2}$-free 0.5 or $1 \mathrm{M}$ sodium hydroxide $(\mathrm{NaOH})$ solution, which is left exposed to air at the sam- 
Table 1. Wellington ${ }^{14} \mathrm{CO}_{2}$ measurement methods through time. Gas counting samples are identified by NZ numbers, AMS samples by NZA numbers. NZ and NZA numbers do not overlap. Sites are Makara (MAK) and Baring Head (BHD). Collection and measurement methods are described in detail in the text.

\begin{tabular}{lrlll}
\hline $\begin{array}{l}\text { Sampling date } \\
\text { range }\end{array}$ & $\begin{array}{r}\text { Sample ID } \\
\text { NZ/NZA }\end{array}$ & Site & $\begin{array}{l}\text { Collection } \\
\text { method }\end{array}$ & $\begin{array}{l}\text { Measurement } \\
\text { method }\end{array}$ \\
\hline $1954-1986$ & $0-7500$ & MAK & tray & gas counting \\
$1987-1994$ & $7500-8400$ & BHD & tray & gas counting \\
$1995-2004$ & $8400-30000$ & BHD & bottle & AMS ENTandem ${ }^{13} \mathrm{C}{ }^{14} \mathrm{C}$ \\
$2005-2009$ & $30000-34000$ & BHD & bottle & AMS ENTandem ${ }^{12} \mathrm{C}{ }^{13} \mathrm{C}{ }^{14} \mathrm{C}$ \\
$2010-2011$ & $34000-50000$ & BHD & bottle & AMS XCAMS \\
$2012-$ present & $50000-$ & BHD & bottle & AMS XCAMS/RG20 \\
\hline
\end{tabular}

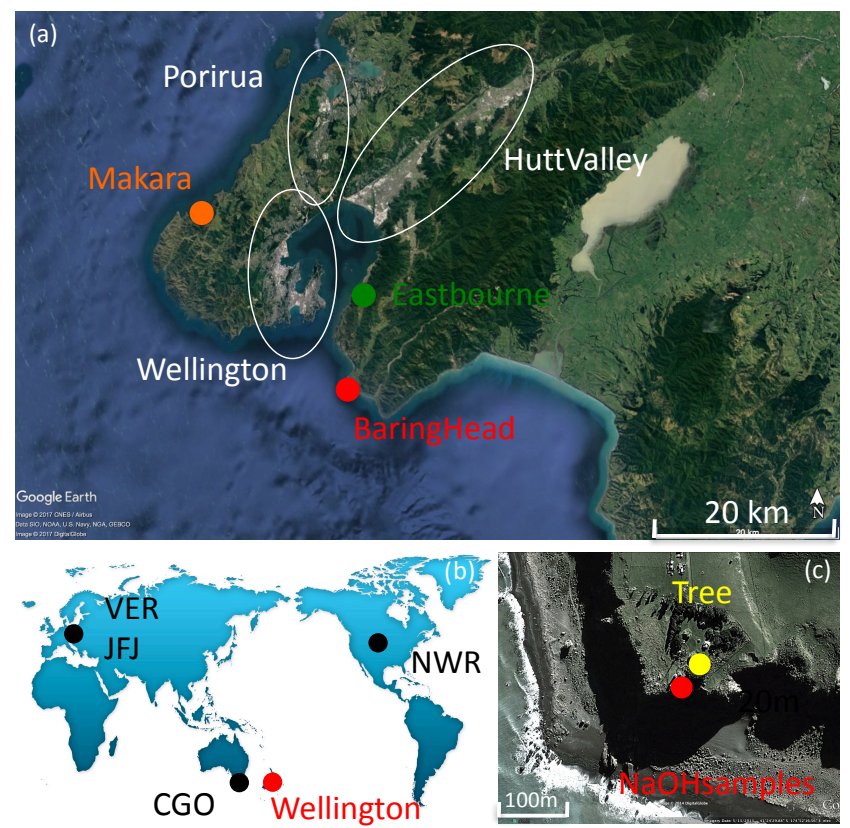

Figure 1. Sampling locations. (a) Makara (1954-1986) and Baring Head (1987-present) air sampling sites, the location of the Eastbourne tree samples, and the urbanized areas of Wellington, Porirua and the Hutt Valley. (b) World location showing Wellington and other sampling sites discussed in the text. (c) Close-up of the Baring Head site showing the relative positions of the air $(\mathrm{NaOH})$ and tree sampling locations.

pling site providing an integrated sample over a period of $\sim 2$ weeks (Sect. S3.1 in the Supplement; Rafter, 1955). From 1954-1995, $2 \mathrm{~L} \mathrm{NaOH}$ solution was exposed to air in a large $\left(\sim 450 \mathrm{~cm}^{2}\right.$ surface area $)$ Pyrex ${ }^{\circledR}$ tray. Since 1995 , wide-mouth high-density polyethylene (HDPE) bottles containing $\sim 200 \mathrm{~mL} \mathrm{NaOH}$ solution were left open inside a Stevenson meteorological screen; the depth of the solution in the bottles remained the same as that in the previously used trays. No significant difference has been observed between the two methods (Currie et al., 2011). A few early (19541970) samples were collected using different vessels, using air pumped through the $\mathrm{NaOH}$ (vs. passive absorption) or by replacing $\mathrm{NaOH}$ with barium hydroxide (Rafter, 1955; Manning et al., 1990). $\mathrm{CO}_{2}$ is extracted from the $\mathrm{NaOH}$ solution by acidification followed by cryogenic distillation (Rafter and Fergusson, 1959; Currie et al., 2011). Static NaOH absorption necessarily fractionates relative to $\mathrm{CO}_{2}$ in the atmosphere. Typical $\delta^{13} \mathrm{C}$ values are -15 to $-25 \%$ for these samples, and this is corrected for in the data analysis.

\subsubsection{Whole-air flasks}

In this study, we use whole-air flask samples collected at Baring Head to supplement and/or replace $\mathrm{NaOH}$ samples. Flasks of whole air are collected by flushing ambient air through the flask for several minutes; they are then filled to slightly over ambient pressure. Most flasks were collected during southerly, clean-air conditions (Stephens et al., 2013). $\mathrm{CO}_{2}$ is extracted cryogenically (Turnbull et al., 2015b). For whole-air samples collected from 1984 to 1993, the extracted $\mathrm{CO}_{2}$ was archived until 2012. We evaluated the quality of this archived $\mathrm{CO}_{2}$ using two methods. Tubes with major leakage were readily detected by air present in the tube and were discarded. $\delta^{13} \mathrm{C}$ from all the remaining samples was in agreement with $\delta^{13} \mathrm{C}$ measured from separate flasks collected at Baring Head and measured for $\delta^{13} \mathrm{C}$ by the Scripps Institution of Oceanography close to the time of collection (http: //scrippsco2.ucsd.edu/data/atmospheric_co2/nzd, Keeling et al., 2001). Whole-air samples collected since 2013 are analysed for $\delta^{13} \mathrm{C}$ and other trace gases and isotopes at NIWA (National Institute of Water and Atmospheric Research, New Zealand) (Ferretti et al., 2000), and for the ${ }^{14} \mathrm{CO}_{2}$ measurement, $\mathrm{CO}_{2}$ is extracted from whole air at the Rafter Radiocarbon Laboratory (Turnbull et al., 2015b).

\subsubsection{Tree rings}

When trees photosynthesize, they faithfully record the $\Delta^{14} \mathrm{C}$ of ambient $\mathrm{CO}_{2}$ in their cellulose, the structural component of wood. Annual tree rings therefore provide a summertime (approximately September-April in the Southern Hemisphere) daytime average $\Delta^{14} \mathrm{CO}_{2}$. Photosynthetic up- 
take varies during the daylight hours depending on factors including growth period, sunlight and temperature (Bozhinova et al., 2013), resulting in a somewhat different effective sampling pattern than the 1-2-week $\mathrm{NaOH}$ solution collections. We show in Sect. 3.5.1 that at the Wellington location this difference is negligible. Note that we assign the mean age of each ring as 1 January of the year in which growth finished (i.e. the mean age of a ring growing from September to April), whereas dendrochronologists assign the "ring year" as the year in which ring growth started (i.e. the previous year).

We collected cores from three trees close to the Baring Head site. A pine (Pinus radiata) located $10 \mathrm{~m}$ from the Baring Head sampling station (Fig. 1) yielded rings back to 1986 (Norris, 2015). A longer record was obtained from two New Zealand kauri (Agathis australis) specimens planted in 1919 and 1920, located $20 \mathrm{~m}$ from one another in Eastbourne, $12 \mathrm{~km}$ from Baring Head (Fig. 1). Kauri is a longlived high-density softwood species that has been widely used in dendrochronology and radiocarbon calibration studies (e.g. Hogg et al., 2013).

Annual rings were counted from each core. Shifting the Eastbourne record by 1 year in either direction moves the ${ }^{14} \mathrm{C}$ bomb spike maximum out of phase with the $\mathrm{NaOH}$-based Wellington $\Delta^{14} \mathrm{CO}_{2}$ record (Supplement Fig. S1), confirming that the ring counts are correct. For the Baring Head pine, rings go back to only 1986, and we verify them by comparing them with the Eastbourne record. They show an insignificant mean difference of $-0.4 \pm 0.8 \%$ (Fig. S1).

In practice, it is difficult to ensure that one annual ring is sampled without losing any material from that ring, and no wood from surrounding rings is included. To evaluate the potential bias from this source, we measured replicate samples from different cores from the same tree (Baring Head) or two different trees (Eastbourne). For samples collected since 1985, all these replicates are consistent within their assigned uncertainties (Fig. S2). However, for three replicates from Eastbourne in 1963, 1965 and 1971, we see large differences of $9.2,44.5$ and $4.9 \%$, which we attribute to small differences in the sampling of the rings that were magnified by the rapid change in $\Delta^{14} \mathrm{C}$ of up to $200 \% \mathrm{yr}^{-1}$ during this period. Thus, the tree ring $\Delta^{14} \mathrm{C}$ values during this period should be treated with caution.

Cellulose was isolated from whole tree rings by first removing labile organics with solvent washes and then oxidizing the resultant material to isolate the cellulose from other materials (Norris, 2015; Hua et al., 2000). The cellulose was combusted and the $\mathrm{CO}_{2}$ purified following standard methods in the Rafter Radiocarbon Laboratory (Baisden et al., 2013).

\section{$2.3{ }^{14} \mathrm{C}$ measurement}

Static $\mathrm{NaOH}$ samples were measured by conventional decay counting on the $\mathrm{CO}_{2}$ gas from 1954 to 1995 (Manning et al., 1990; Currie et al., 2011), and these samples are identi- fied by their unique "NZ" numbers. All measurements made since 1995, including recent measurements of flask samples collected in the 1980s and 1990s, were reduced to graphite, measured by accelerator mass spectrometry (AMS), and are identified by their unique "NZA" numbers. The LG1 graphitization system was used from 1995 to 2011 (NZA < 50 000; Lowe and Judd, 1987), and replaced with the RG20 graphite system in 2011 (NZA > 50 000; Turnbull et al., 2015b). Samples measured by AMS were stored for up to 3 years between sample collection and extraction, graphitization and measurement.

For samples collected from 1995 to 2010, an EN Tandem AMS was used for measurement (NZA $<35000$; Zondervan and Sparks, 1996). Until 2005 (NZA $<30000$, including all previously reported Wellington ${ }^{14} \mathrm{CO}_{2}$ data), only ${ }^{13} \mathrm{C}$ and ${ }^{14} \mathrm{C}$ were measured on the EN Tandem system, so the normalization correction for isotopic fractionation (Stuiver and Polach, 1977) was performed using an offline isotope ratio mass spectrometer $\delta^{13} \mathrm{C}$ value. The data reported from 2005 onwards (NZA > 30000) show a reduction in scatter reflecting the addition of online ${ }^{12} \mathrm{C}$ measurement in the EN Tandem system in 2005. This allows direct online correction for isotopic fractionation that may occur during sample preparation and in the AMS system (Zondervan et al., 2015) and results in improved long-term repeatability. Fractionation in the AMS system may vary in sign depending on the particular conditions, but incomplete graphitization biases the graphite towards lighter isotopes, which, if undiagnosed, will bias $\Delta^{14} \mathrm{C}$ high. The LG1 graphitization system used during this period did not directly evaluate whether graphitization was complete, so it is possible or even likely that there was a high bias in the 1995-2005 measurements. This is further discussed in Sect. 3.5.3.

For all EN Tandem samples, a single large aliquot of extracted $\mathrm{CO}_{2}$ was split into four separately graphitized and measured targets and the results of all four were averaged. We have revisited the multi-target averaging, applying a consistent criterion to exclude outliers and using a weighted mean of the retained measurements (Supplement). This results in differences of up to $5 \%$ relative to the values reported by Currie et al. (2011) and is discussed in more detail in the Supplement.

In 2010, the EN Tandem was replaced with a National Electrostatics Corporation AMS, dubbed XCAMS $(\mathrm{NZA}>34000)$. XCAMS measures all three carbon isotopes, such that the normalization correction is performed using the AMS-measured ${ }^{13} \mathrm{C}$ values (Zondervan et al., 2015). XCAMS measurements are made on single graphite targets measured to high precision of typically $1.8 \%$ (Turnbull et al., 2015b).

\subsection{Results format}

$\mathrm{NaOH}$ samples are collected over a period of typically 2 weeks and sometimes much longer. We report the date of 
collection as the average of the start and end dates. In cases where the end date was not recorded, we use the start date. For a few samples, the sampling dates were not recorded or are ambiguous, and those results have been excluded from the reported dataset.

Results are reported here as $\mathrm{F}^{14} \mathrm{C}$ (Reimer et al., 2004) and $\Delta^{14} \mathrm{C}$ (Turnbull et al., 2007). $\mathrm{F}^{14} \mathrm{C}$ is corrected for isotopic fractionation and blank corrected. We calculated $\mathrm{F}^{14} \mathrm{C}$ from the original measurement data recorded in our databases and updated a handful of records where transcription errors were found. $\triangle^{14} \mathrm{C}$ is derived from $\mathrm{F}^{14} \mathrm{C}$ and corrected for radioactive decay since the time of collection; this is slightly different from $\Delta{ }^{14} \mathrm{C}$ as defined by Stuiver and Polach (1977), which is corrected to the date of measurement. $\Delta^{14} \mathrm{C}$ has been recalculated using the date of collection for all results, resulting in changes of a few tenths of per mil in most $\Delta^{14} \mathrm{C}$ values relative to those reported by Currie et al. (2011) and Manning et al. (1990). Uncertainties are reported based on the counting statistical uncertainty, and for AMS measurements, we add an additional error term, determined from the long-term repeatability of secondary standard materials (Turnbull et al., 2015b; Sect. S5.3). Samples for which changes have been made relative to the previously published results are indicated by the quality flag provided in the Supplement dataset. Where more than one measurement was made for a given date, we report the weighted mean (Bevington and Robinson, 2003) of all measurements.

\subsection{Smooth curve fits}

In addition to the raw measured $\Delta^{14} \mathrm{CO}_{2}$ values, we calculate a smooth curve fit and deseasonalized trend from the Wellington $\Delta^{14} \mathrm{C}$ and $\mathrm{F}^{14} \mathrm{C}$ datasets. The deseasonalized trend may be more useful than the raw data for the aging of recent materials (e.g. Reimer et al., 2004; Hua et al., 2013). Acknowledging that the 1995-2005 period is variable and possibly biased in the Wellington record (Sect. 4.3), we also provide in the Supplement an alternative midlatitude Southern Hemisphere smooth curve fit and deseasonalized trend in which the Wellington data for 1995-2005 has been removed and replaced with the Cape Grim, Tasmania, data for that period (Levin et al., 2010).

Curve fitting is particularly challenging for the $\Delta^{14} \mathrm{CO}_{2}$ record since (a) there are data gaps and inconsistent sampling frequency, (b) the growth rate and trend vary dramatically, and (c) the seasonal cycle changes both in magnitude and phase (Sect. 5.2). We chose to use the CCGCRV fitting procedure (Thoning et al., 1989; www.esrl.noaa.gov/gmd/ $\mathrm{ccgg} / \mathrm{mbl} / \mathrm{crvfit} /$ ), which can readily handle the data gaps, inconsistent sampling frequency and rapid changes in the trend. To address the changing seasonal cycle, we make separate fits to the record for five time periods: 1954-1965, 1966-1979, 1980-1989, 1990-2004 and 2005-2014. These divisions were chosen based on major changes in the raw observational growth rate, seasonal cycle and data quality
(Sect. S6). For each time period, we use CCGCRV with one linear and two harmonic terms, and fit residuals are added back using a low-pass filter with an 80-day cut-off in the frequency domain. At each transition, we overlapped a 2-year period and linearly interpolated the two fits across that 2year period to smooth the transitions caused by end effects. The $1 \sigma$ uncertainty in the smoothed curve and deseasonalized trend were determined using a Monte Carlo technique. Further details of the fitting procedure and choice of time period cut-offs are provided in the Supplement.

The mean difference between the fitted curve and the measured $\Delta^{14} \mathrm{CO}_{2}$ values is $3.8 \%$, consistent with the typical measurement uncertainty for the full dataset. Further, the residuals are highest for the early period (1954-1970) at 6\%o, consistent with the larger measurement errors at that time of $\sim 6 \%$. The residuals improve as the measurement errors reduce, such that since 2005 , the mean residual is $2 \%$, consistent with the reported $2 \%$ uncertainties. The exception is the 1995-2005 period where the mean residual difference of $5 \%$ is substantially higher than the mean reported uncertainty of $2.5 \%$, reflecting the apparent larger scatter during this period (Sect. 4.3).

\section{Data validation}

\subsection{Tree ring comparison}

Over the more than 60 years of the Wellington $\Delta^{14} \mathrm{CO}_{2}$ record, there have necessarily been many changes in methodology, and the tree rings provide a way to validate the full record, albeit with lower resolution. Due to the possible sampling biases in the tree rings (Sect. 3.2.3.), we do not include them in the final updated record but use them to validate the existing measurements.

During the rapid $\Delta^{14} \mathrm{CO}_{2}$ change in the early 1960s, there are some differences between the kauri tree ring and Wellington $\Delta^{14} \mathrm{CO}_{2}$ records (Fig. 2). The 1963 and 1964 tree ring samples are slightly lower than the concurrent $\Delta^{14} \mathrm{CO}_{2}$ samples. The peak $\Delta^{14} \mathrm{CO}_{2}$ measurement in the tree rings is $30 \%$ o lower than the smoothed $\Delta^{14} \mathrm{CO}_{2}$ record and $100 \%$ lower than the two highest $\Delta^{14} \mathrm{CO}_{2}$ measurements in 1965 . These differences are likely due to small errors in the sampling of the rings, which will be most apparent during periods of rapid change.

Prior to 1960 and from the peak of the bomb spike in 1965 until 1990, there is remarkable agreement between the tree rings and Wellington $\Delta^{14} \mathrm{CO}_{2}$ record, with the variability replicated in both records. Since 2005, there is excellent agreement across all the different records. Some differences are observed in 1990-1993 and 1995-2005, which we discuss in the following sections. 

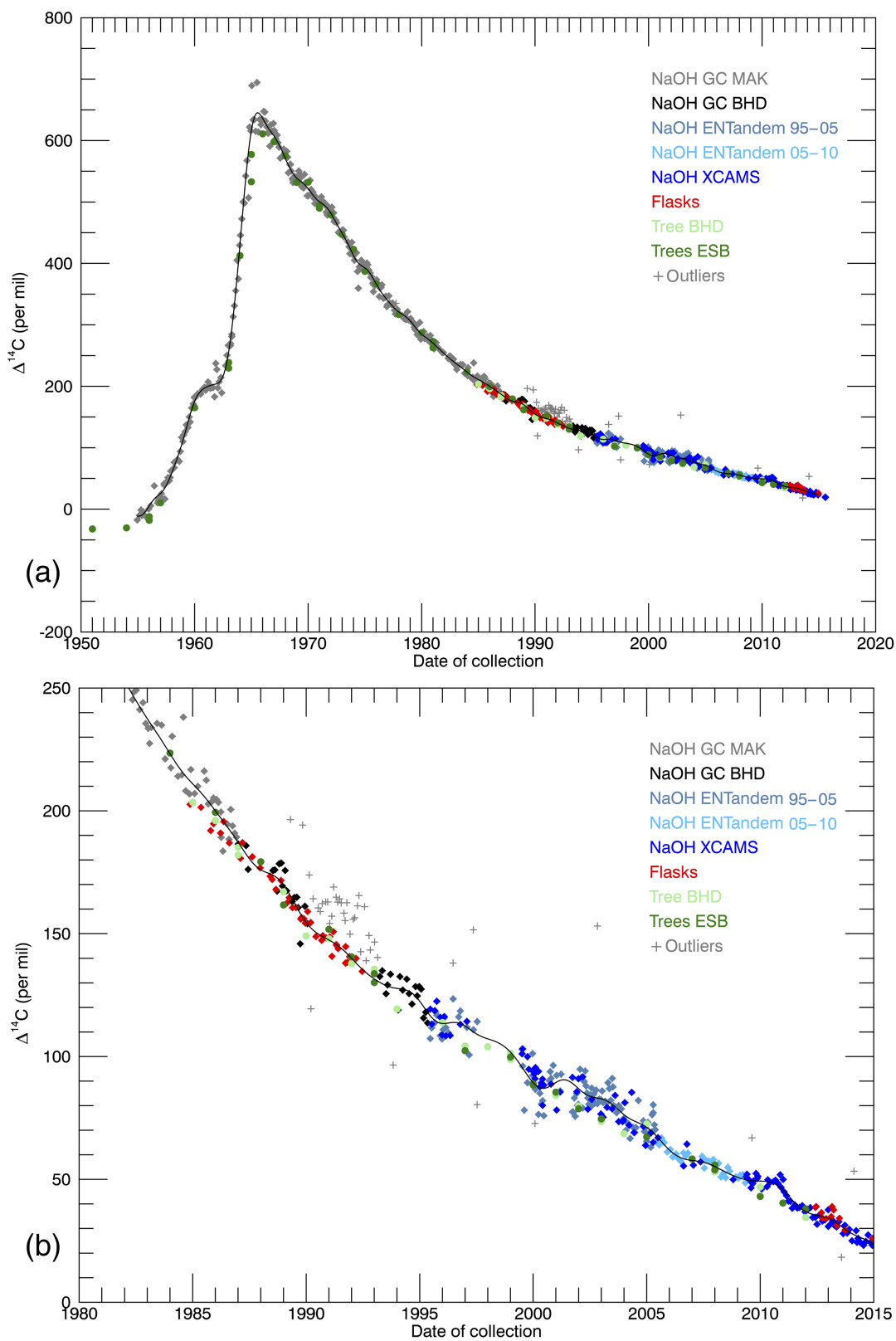

Figure 2. Wellington ${ }^{14} \mathrm{CO}_{2}$ record showing all collection and measurement methods for the full record (a) and zoomed in for the period since 1980 (b). Tree rings (green) and outliers (grey pluses) are excluded from the reported final dataset. The black line is the smooth curve fit to the final dataset.

\subsection{0-1993 anomaly}

An anomaly in the gas counting measurements between 1990 and 1993 has previously been noted (Figs. 2, 3) as a deviation from the Cape Grim $\Delta^{14} \mathrm{CO}_{2}$ record (CGO; $40.68^{\circ} \mathrm{S}$, $144.68^{\circ} \mathrm{E}$; $94 \mathrm{ma.s.1}$; Levin et al., 2010) during the same period. Cape Grim is at similar latitude, and observes a mixture of air from the midlatitude Southern Ocean sector and mainland Australia (Ziehn et al., 2014; Law et al., 2010). The Wellington and Cape Grim records overlap during almost all other periods (Fig. 3).
We use archived $\mathrm{CO}_{2}$ from flask samples to evaluate this period of deviation. First, the recent flask samples collected since 2013 ( $n=12)$ agree very well with the $\mathrm{NaOH}$ static samples from the same period (Fig. 2), indicating that despite the difference in sampling period for the two methods, flask samples reflect the $\Delta^{14} \mathrm{CO}_{2}$ observed in the longer-term $\mathrm{NaOH}$ static samples. We then selected a subset of archived 1984-1992 extracted $\mathrm{CO}_{2}$ samples for measurement, mostly from southerly wind conditions but including a few from other wind conditions. These flask $\Delta^{14} \mathrm{CO}_{2}$ measurements 
do not exhibit the anomaly seen in the $\mathrm{NaOH}$ static samples (Fig. 2), implying that the deviation observed in the original $\mathrm{NaOH}$ static samples may be a consequence of sampling, storage or measurement errors. Annual tree rings from both the kauri and pine follow the flask measurements for this period (Fig. 2), confirming that the $\mathrm{NaOH}$ static samples are anomalous.

The 1990-1993 period was characterized by major changes in New Zealand science, both in the organizational structure and personnel. Although we are unable to exactly reconstruct events at that time, we hypothesize that the $\mathrm{NaOH}$ solution was prepared slightly differently, perhaps omitting the barium chloride precipitation step for these samples. This would result in contaminating $\mathrm{CO}_{2}$ absorbed on the $\mathrm{NaOH}$ before the solution was prepared. Since atmospheric $\Delta^{14} \mathrm{CO}_{2}$ is declining, this would result in higher $\Delta^{14} \mathrm{CO}_{2}$ observed in these samples than in the ambient air. Another possibility is that there were known issues with the background contamination in the proportional counters during this period that could result in a high-bias $\Delta^{14} \mathrm{CO}_{2}$. In any case, these values are anomalous, and we remove the original $\mathrm{NaOH}$ static sample measurements between 1990 and 1993 and replace them with the new flask measurements for the same period.

\section{$3.3 \quad 1995-2005$ variability}

As already discussed in Sect. 3.3, the measurement method was changed from gas counting to AMS for samples collected in 1995 and thereafter. During the first 10 years of AMS measurements, the record is much noisier than during any other period (Fig. 2). Until 2005, offline $\delta^{13} \mathrm{C}$ measurements on the evolved $\mathrm{CO}_{2}$ were used in the normalization correction. In 2005 , online ${ }^{12} \mathrm{C}$ measurement was added to the AMS system, allowing online AMS measurement of the $\delta^{13} \mathrm{C}$ value and accounting for any fractionation during sample preparation and AMS measurement (Zondervan et al., 2015; see also Sect. 3.3). This substantially improved the measurement accuracy, and the noise in the $\Delta^{14} \mathrm{CO}_{2}$ record immediately reduced as can be seen in the lower panel of Fig. 2. Therefore, we suspect that the variability and apparent high bias in the 1995-2005 period of the $\Delta^{14} \mathrm{CO}_{2}$ record is due to measurement uncertainty and bias rather than atmospheric variability.

The remaining $\mathrm{NaOH}$ solution for all samples collected since 1995 has been archived, and typically only every second sample collected was measured, with the remainder archived without extraction. In 2011-2016, we revisited the 1995-2005 period, remeasuring some samples that had previously been measured and some that had never been measured for a total of 52 new analyses.

The new measurements for this time period do show reduced scatter over the original analyses, particularly for the period from 1998 to 2001, when the original analyses appear anomalously low, and in 2002-2003, when the original

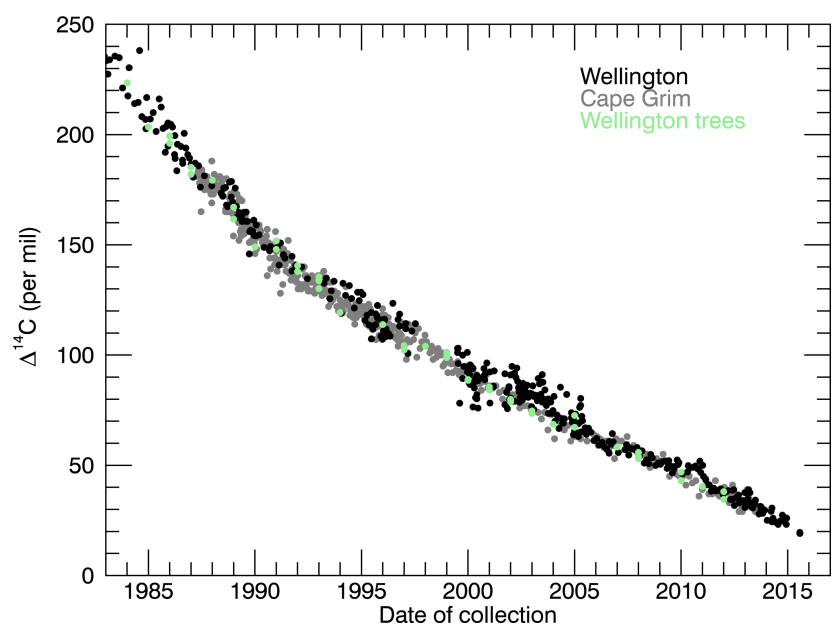

Figure 3. Comparison of the final Wellington and Cape Grim (Levin et al., 2010) $\Delta{ }^{14} \mathrm{CO}_{2}$ records. Wellington tree ring measurements are also shown.

analyses appear anomalously high. Yet there remain a number of both low and high outliers in the new measurements. These are present in both the samples that were remeasured and in those for which this was the first extraction of the sample. This suggests that a subset of the archived sample bottles were either contaminated at the time of collection or that some bottles were insufficiently sealed, causing contamination with more recent $\mathrm{CO}_{2}$ during storage. Comparison with the tree ring measurements and with the Cape Grim record (Levin et al., 2010) suggests that the measurements during this period may, on average, be biased high as well as having additional scatter (Fig. 3). Nonetheless, in the absence of better data, we retain both the original and remeasured $\mathrm{NaOH}$ sample results in the full Wellington record, with a special flag to allow users to easily remove the questionable results if they prefer. We also provide a smoothed fit that excludes these data (Sect. 3.6).

\section{Results and discussion}

\subsection{Variability in the Wellington record through time}

The Wellington $\Delta^{14} \mathrm{CO}_{2}$ record begins in December 1954, at a roughly pre-industrial $\Delta^{14} \mathrm{CO}_{2}$ level of $-20 \%$ (Fig. 2). From $1955, \Delta{ }^{14} \mathrm{CO}_{2}$ increased rapidly, near-doubling to $700 \%$ in 1965 at Wellington, due to the production of ${ }^{14} \mathrm{C}$ during atmospheric nuclear weapons tests. Nuclear tests in the early 1950 s contributed to the rise; then a hiatus in testing in the late 1950s led to a plateau in Wellington $\Delta^{14} \mathrm{CO}_{2}$ before a series of very large atmospheric tests in the early 1960s led to further increases (Rafter and Ferguson, 1959; Manning et al., 1990).

Most atmospheric nuclear weapons testing ceased in 1963, and the Wellington $\Delta^{14} \mathrm{CO}_{2}$ record peaks in 1965 and then 
begins to decline, at first rapidly at $-30 \% \mathrm{yr}^{-1}$ in the $1970 \mathrm{~s}$ and gradually slowing to $-5 \% \mathrm{yr}^{-1}$ after 2005 . The initial rapid decline has been attributed primarily to the uptake of the excess radiocarbon into the oceans and, to a lesser extent, to uptake into the terrestrial biosphere (Naegler et al., 2006; Randerson et al., 2002; Manning et al., 1990; Stuiver and Quay, 1981). The short residence time of carbon in the biosphere means that from the 1980s, the terrestrial biosphere changed from a ${ }^{14} \mathrm{C}$ sink to a ${ }^{14} \mathrm{C}$ source as the bomb pulse was re-released (Randerson et al., 2002; Levin et al., 2010).

Natural cosmogenic production of ${ }^{14} \mathrm{C}$ damps the rate of decline since the bomb peak by $\sim 5 \%$ yr ${ }^{-1}$ in $\Delta{ }^{14} \mathrm{CO}_{2}$; this may vary with the solar cycle, but there is no known longterm trend in this component of the signal (Turnbull et al., 2009b; Naegler et al., 2006). There is also a small positive contribution from the nuclear industry, which emits ${ }^{14} \mathrm{C}$ to the atmosphere, and this has increased from 0 in the 1950s to $0.5-1 \% \circ \mathrm{yr}^{-1}$ in the last decade (Turnbull et al., 2009b; Levin et al., 2010; Graven and Gruber, 2011).

The Suess effect, the decrease in atmospheric $\Delta^{14} \mathrm{CO}_{2}$ due to the addition of ${ }^{14} \mathrm{C}$-free fossil fuel $\mathrm{CO}_{2}$ to the atmosphere (Suess, 1955; Tans et al., 1979; Levin et al., 2003), was first recognized in 1955 and has played a role throughout the record. Although the magnitude of fossil fuel $\mathrm{CO}_{2}$ emissions has grown through time, when convolved with the declining atmospheric $\Delta^{14} \mathrm{CO}_{2}$ history, the impact on $\Delta^{14} \mathrm{CO}_{2}$ stayed roughly constant at $-10 \% \mathrm{yr}^{-1}$ from the 1970 s to the mid2000s (Randerson et al., 2002; Levin et al., 2010; Graven et al., 2012). Yet the continued increase in fossil fuel $\mathrm{CO}_{2}$ emissions has slightly increased the impact of fossil fuel $\mathrm{CO}_{2}$ in the last few years, to about $-12 \% \mathrm{yr}^{-1}$ in 2014 (using annual global fossil fuel $\mathrm{CO}_{2}$ estimates from CDIAC (Carbon Dioxide Information Analysis Center); Boden et al., 2017). Since the 1990s, the Suess effect has been the largest driver of the ongoing negative growth rate (Turnbull et al., 2009b; Levin et al., 2010).

The most recent part of the Wellington $\Delta^{14} \mathrm{CO}_{2}$ record from 2005-2014 is reported here for the first time. It shows a continuing downward trend in $\Delta^{14} \mathrm{CO}_{2}$ of $-5 \% \circ \mathrm{yr}^{-1}$ and a slight slowing in the negative trend relative to the 1990 2004 period, which had a trend of $5.8 \% \mathrm{orr}^{-1}$. This slight slowing in the downward $\Delta^{14} \mathrm{CO}_{2}$ trend is the opposite of what might be expected due to the Suess effect alone. Possible explanations are a slowing of the rate of uptake of ${ }^{14} \mathrm{C}$ into the oceans, an increase in the return rate of bomb ${ }^{14} \mathrm{C}$ to the atmosphere from the biosphere and a long-term increase in ${ }^{14} \mathrm{C}$ production.

\subsection{Seasonal variability in the Wellington record}

We determine the changing seasonal cycle from smooth curve fits to five separate periods of the record (1954-1965, 1966-1979, 1980-1989, 1990-2004, 2005-2014; Fig. 4a). This subdivision is necessary to allow the seasonal cycle to vary through time since the CCGCRV curve fitting routine
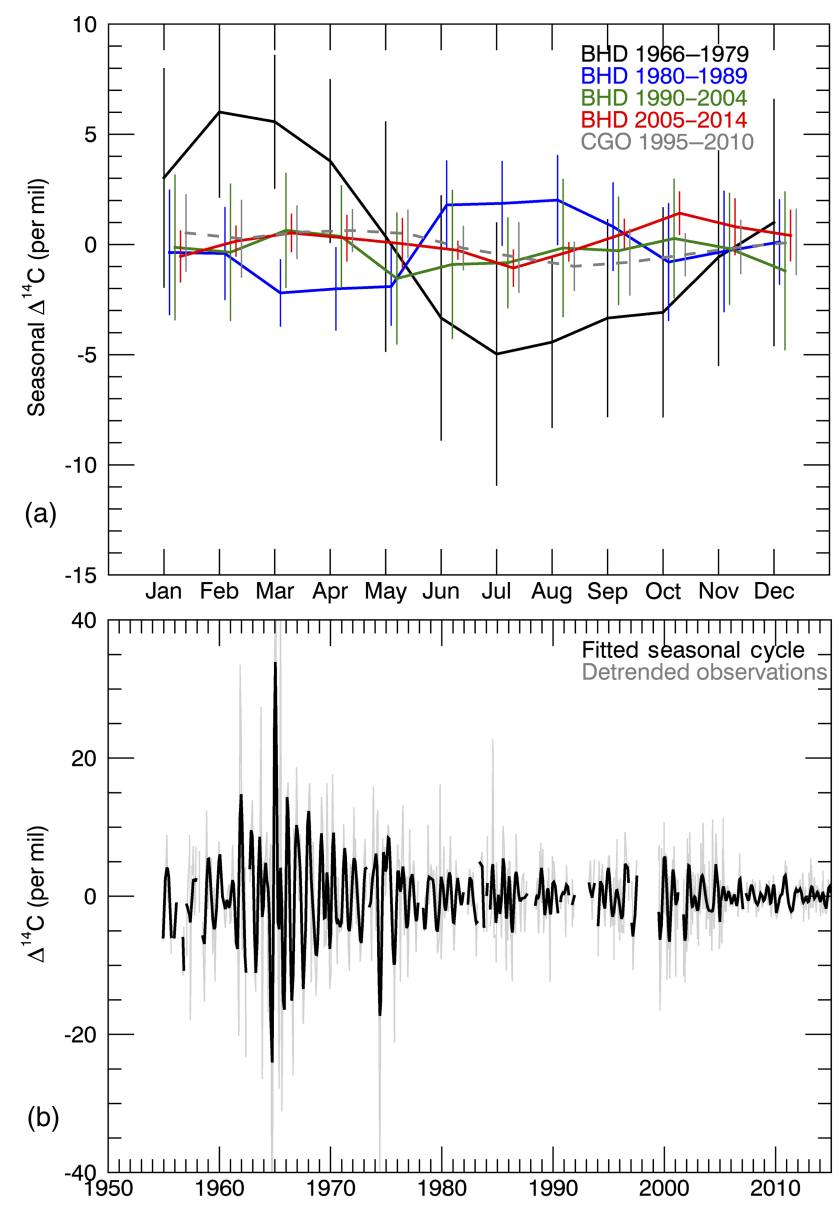

Figure 4. Detrended seasonal cycle in the Wellington $\Delta^{14} \mathrm{CO}_{2}$ record. (a) BHD monthly detrended seasonal cycle averaged over four time periods as described in the text and the CGO (Levin et al., 2010) detrended seasonal cycle. Error bars are the standard deviation of all years averaged. Points for each time period are slightly offset for clarity. (b) Full seasonal cycle record determined separately for each time period shown in (a) plus 1954-1965 (black) and detrended observations without any smoothing (grey).

assigns a single set of harmonics to the time period fitted (see Sect. 3.5). The choice of time periods is discussed in Sect. S6. We also created detrended, fitted $\Delta^{14} \mathrm{CO}_{2}$ seasonal cycles by subtracting the deseasonalized trend from the observations. Comparison with the detrended, fitted seasonal cycle determined from the smooth curve fits (Fig. 4b) shows that the smooth curve fit, as might be expected, does not capture the largest deviations from the trend seen in the observations but represents the changing seasonal cycle quite well.

The 1966-1979 period shows a strong seasonal cycle (Fig. 4) with a consistent phase and an amplitude that varies from a maximum in 1966 of $30 \%$ gradually declining to $3 \%$ o in 1979 , with a mean amplitude of about $6 \%$. This is primarily attributed to seasonally varying stratosphere-troposphere exchange bringing bomb ${ }^{14} \mathrm{C}$ into the troposphere (Manning et al., 1990; Randerson et al., 2002). Manning et al. (1990) 
were unable to simulate the correct phasing of the seasonal cycle, apparently because their model distributed bomb ${ }^{14} \mathrm{C}$ production throughout both the northern and southern stratosphere. In fact, the majority of the bomb ${ }^{14} \mathrm{C}$ was produced in the Northern Hemisphere stratosphere (Enting et al., 1982). Randerson et al. (2002) were able to match the amplitude of the Wellington seasonal cycle during this time period, although their model was out of phase with the observations by about 1.5 months. They attribute the seasonal cycle during this period mostly to the seasonality in Northern Hemisphere stratosphere-troposphere exchange with a phase lag caused by cross-equator exchange into the Southern Hemisphere. The seasonal cycle kept the same phase but gradually decreased in amplitude until the late 1970s, attributed to the declining disequilibrium between the stratosphere and troposphere as the bomb ${ }^{14} \mathrm{C}$ moved throughout the carbon reservoirs.

Between 1978 and 1980 the seasonal cycle weakened and then reversed during the 1980s, with a maximum in winter (June-August) and an amplitude of about $2 \%$. The detrended observations show that this change in phase is not an artefact of the fitting method (Fig. 4b). This result is comparable to that obtained by Manning et al. (1990) and Currie et al. (2011), who both used a seasonal trend loss (STL) procedure to determine the seasonal cycle from the same data. This is consistent with the seasonality in atmospheric transport convolving with a change in sign of the terrestrial biosphere contribution as the bomb ${ }^{14} \mathrm{C}$ pulse began to return to the atmosphere from the biosphere (Randerson et al., 2002).

The Wellington $\Delta^{14} \mathrm{CO}_{2}$ seasonal cycle declined in the 1990s, and the larger variability in the observations between 1995 and 2005 makes it difficult to discern a seasonal cycle during that period. Since 2005, the more precise measurements allow us to detect a small seasonal cycle with an amplitude of about $2 \%$ (Fig. 4). We compare the seasonal cycle at Wellington from 2005 to 2015 with the seasonal cycle at Cape Grim, Australia, from 1995 to 2010. There is no significant difference in the seasonal cycle at either site if we select only the overlapping time period of 2005-2010. Both sites show a similar magnitude seasonal cycle during this period, and Cape Grim shows a maximum in March-April that has been attributed primarily to the seasonality of atmospheric transport of Northern Hemisphere fossil fuel emissions to the southern troposphere (Levin et al., 2010). This maximum at Cape Grim coincides with a seasonal maximum in the Wellington record. However, Wellington $\Delta^{14} \mathrm{CO}_{2}$ exhibits a second maximum in the austral spring (October) that is not apparent at Cape Grim.

Recent work has shown that during the winter, the Cape Grim station is influenced by air coming off the Australian mainland, including the city of Melbourne (Ziehn et al., 2014), which would act to reduce $\Delta^{14} \mathrm{CO}_{2}$ at Cape Grim relative to Southern Ocean clean air. This shift is shown to be the result of seasonal variations in atmospheric transport. The 2-week integrated sampling used for $\Delta^{14} \mathrm{CO}_{2}$ at both
Cape Grim and Baring Head means that in contrast to other species, $\Delta^{14} \mathrm{CO}_{2}$ measurements cannot be screened to remove these pollution events.

In contrast, the Baring Head location near Wellington does not show significant seasonal variation in atmospheric transport (Steinkamp et al., 2017) and Baring Head is less likely than Cape Grim to be influenced by anthropogenic emissions in any season. Air is typically from the ocean, and the local geography means that the urban emission plume from Wellington and its northern suburbs of Lower Hutt very rarely passes over Baring Head (Fig. 1), and the typically high wind speeds further reduce the influence of the local urban area (Stephens et al., 2013). During the austral autumn, there is some land influence from the Christchurch region in the South Island, but emissions from Christchurch are much smaller than the Melbourne emissions influencing Cape Grim: State of Victoria fossil fuel $\mathrm{CO}_{2}$ emissions for 2013 were $23 \mathrm{MtC}$, whereas Wellington and Christchurch each emitted $0.4 \mathrm{MtC}$ of fossil fuel $\mathrm{CO}_{2}$ in 2013 (Boden et al., 2017; AECOM, 2016; Australian Government, 2016).

Although broad-scale flow from the west is common, the local topography means that local air flow is almost always either southerly or northerly (Stephens et al., 2013), but during rare ( $<5 \%$ of the time) westerly wind events, fossil fuel emissions from Wellington do appear to cause enhancements of up to $2 \mathrm{ppm}$ in $\mathrm{CO}_{2}$ (Stephens et al., 2013), which would decrease $\Delta{ }^{14} \mathrm{CO}_{2}$ by $\sim 1 \%$ o during such an event. Yet there is no evidence of seasonality in the infrequent westerly events. Northerly conditions bring a terrestrial biosphere influence that elevates $\mathrm{CO}_{2}$ by about $1 \mathrm{ppm}$ (Stephens et al., 2013), which could result in a maximum increase in $\Delta^{14} \mathrm{CO}_{2}$ of $\sim 0.2 \%$ o relative to background conditions, but there is no evidence that this influence is seasonally variable either. Thus, although there are some local influences on the Baring Head $\Delta^{14} \mathrm{CO}_{2}$, none of these appear to be seasonally dependent and instead, the observed Baring Head $\Delta^{14} \mathrm{CO}_{2}$ maximum in spring in the recent part of the record may be explained by the seasonal maximum in cross-tropopause exchange bringing ${ }^{14} \mathrm{C}$-enriched air at this time of year.

\subsection{Comparison with other atmospheric $\Delta^{14} \mathrm{CO}_{2}$ records}

We compare the Wellington $\Delta^{14} \mathrm{CO}_{2}$ record with several other $\Delta^{14} \mathrm{CO}_{2}$ records, located as indicated in Fig. 1. First, we compare it with measurements from Cape Grim, Australia $\left(\mathrm{CGO} ; 40.68^{\circ} \mathrm{S}, 144.68^{\circ} \mathrm{E} ; 94 \mathrm{~m}\right.$ a.s.l.). Cape Grim is at similar latitude to Wellington and also frequently receives air from the Southern Ocean (Levin et al., 2010). Samples are collected by a similar method to the Wellington record using $\mathrm{NaOH}$ absorption and are measured by gas counting to $\sim 2 \%$ precision. Next, we compare them with midlatitude high-altitude clean-air sites in the Northern Hemisphere. The Vermunt, Austria (VER, $47.07^{\circ} \mathrm{N}, 9.57^{\circ} \mathrm{E}$, $1800 \mathrm{~m}$ a.s.l.), record began in 1958 , only a few years after 
Table 2. $\Delta^{14} \mathrm{CO}_{2}$ gradients between sites, determined as the mean of the monthly differences for each time period. Errors are the standard deviation of the monthly differences.

\begin{tabular}{lrr}
\hline Site difference & Time period & $\begin{array}{r}\Delta^{14} \mathrm{CO}_{2} \text { difference } \\
(\% \circ)\end{array}$ \\
\hline BHD-CGO & $1986-1990$ & $1.8 \pm 2.5$ \\
BHD-CGO & $2005-2013$ & $1.3 \pm 3.4$ \\
BHD-JFJ & $1986-1990$ & $0.8 \pm 3.9$ \\
BHD-JFJ & $2005-2013$ & $4.8 \pm 2.7$ \\
BHD-NWR & $2005-2013$ & $6.9 \pm 2.5$ \\
\hline
\end{tabular}

the Wellington record began, and in the 1980s the site was moved to Jungfraujoch, Switzerland (JFJ, $46.55^{\circ} \mathrm{N}, 7.98^{\circ} \mathrm{E}$, $3450 \mathrm{~m}$ a.s.1.); these measurements are made in the same manner and by the same laboratory as the Cape Grim record (Levin et al., 2013). We also consider the Niwot Ridge, USA $\Delta^{14} \mathrm{CO}_{2}$ record (NWR, $40.05^{\circ} \mathrm{N}, 105.59^{\circ} \mathrm{W}, 3523 \mathrm{~m}$ a.s.l.), which began in 2003 (Turnbull et al., 2007; Lehman et al., 2013). Niwot Ridge is also a midlatitude, high-altitude site, but samples are collected as whole air in flasks and measured by AMS in a similar manner to that described for the Wellington flask samples. Thus, we are comparing two independent Southern Hemisphere records with two independent Northern Hemisphere records, with the two hemispheres tied together by the common measurement laboratory used for Cape Grim and Jungfraujoch. Results from all records are compared in Fig. 5.

The Wellington and Cape Grim records are generally consistent with one another (Fig. 3), with the exception of the 1995-2005 period, when the Wellington record is slightly higher, apparently due to bias in the Wellington record (discussed in Sect. 3.5.3.). Differences between the sites are smaller than the measurement uncertainty for all other periods (Table 2). This implies that $\Delta^{14} \mathrm{CO}_{2}$ is homogeneous across Southern Hemisphere clean-air sites within the same latitude band, at least since the 1980s when the two records overlap. Similarly, the high-altitude, midlatitude Northern Hemisphere sites are consistent with one another, although there are some differences in seasonal cycles in recent years (Turnbull et al., 2009b).

The bomb spike maximum is higher and earlier in the Northern Hemisphere records (Fig. 5), consistent with the production of most bomb ${ }^{14} \mathrm{C}$ in the Northern Hemisphere stratosphere. We make a new, simple estimate of the interhemispheric exchange time during the 1963-1965 period using the difference in the timing of the Northern and Southern Hemisphere bomb peaks. The first maximum of the bomb peak was in July 1963 in the Northern Hemisphere and January 1965 in the Southern Hemisphere, a 1.4-year offset, implying a 1.4-year exchange time. This is consistent with other more detailed interhemispheric exchange time estimates that
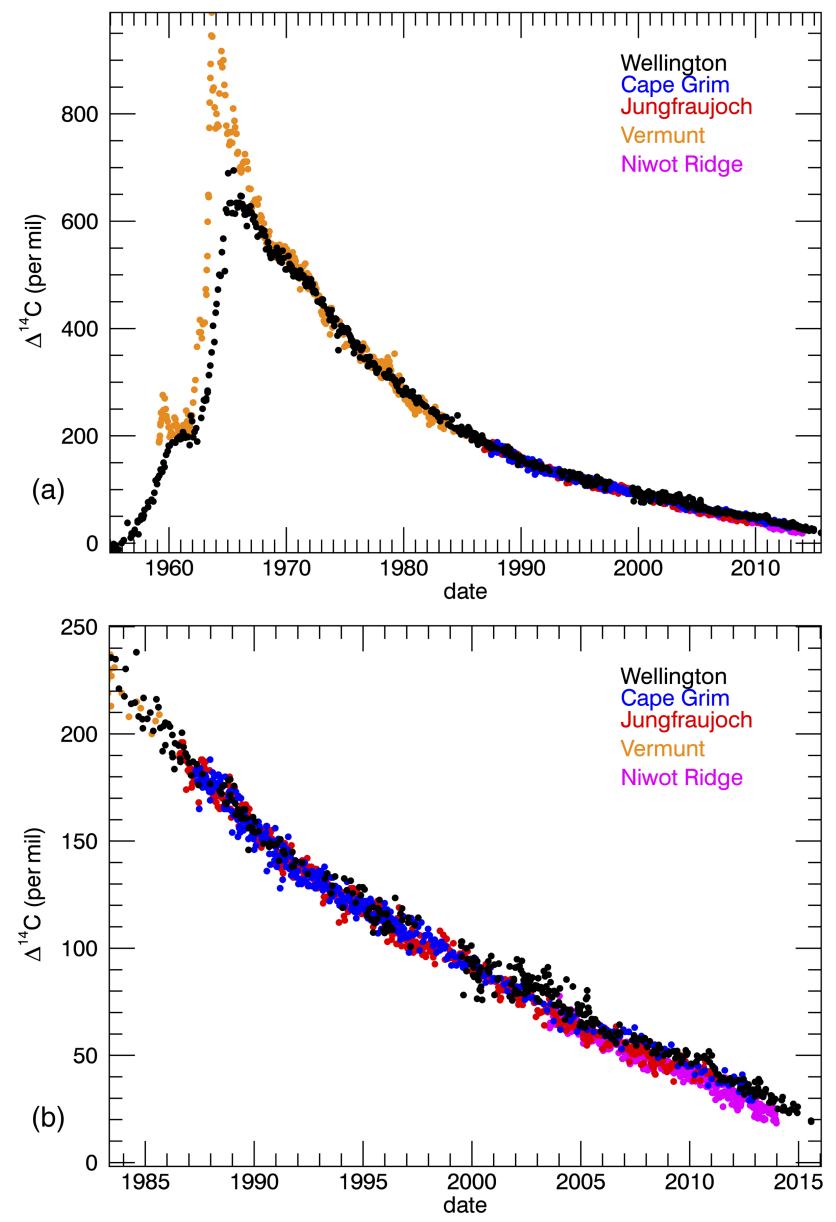

Figure 5. Comparison of Wellington and other atmospheric $\Delta^{14} \mathrm{CO}_{2}$ records (Levin et al., 2010; Turnbull et al., 2007; Lehman et al., 2013).

have been determined from long-term measurements of $\mathrm{SF}_{6}$ of 1.3 to 1.4 years (Geller at el., 1997; Patra et al., 2011).

Northern Hemisphere ${ }^{14} \mathrm{CO}_{2}$ remains higher than Southern Hemisphere $\Delta^{14} \mathrm{CO}_{2}$ by about $20 \%$ until 1972. Although most nuclear weapons testing ceased in 1963, a few smaller tests continued in the late $1960 \mathrm{~s}$, contributing to this continued interhemispheric offset (Enting, 1982). The interhemispheric gradient disappeared within about 1.5 years after atmospheric testing essentially stopped in 1970. Except for periods of noisy data from Vermunt in the late 1970s and Wellington in 1995-2005, there are only small $(<2 \%$ o) interhemispheric gradients from 1972 until 2002 (Fig. 5, Table 2).

As previously noted by Levin et al. (2010), using a shorter dataset, an interhemispheric gradient of 5-7\%o develops in 2002, with the Southern Hemisphere sites higher than the Northern Hemisphere sites (Table 2). We choose 1986-1990 and 2005-2013 as time periods to compare, to avoid the periods where the Wellington record is noisy (1995-2005) and where we substituted flask measurements from 1990 to 1993. In 1986-1990, there is less than $2 \%$ o difference between 
Wellington and either Cape Grim or Jungfraujoch. There is also no difference between the Cape Grim and Jungfraujoch records during this time period. The Wellington and Cape Grim records still agree within $2 \%$ after 2005, but both Jungfraujoch and Niwot Ridge diverge from Wellington, by $4.8 \pm 2.7$ and $6.9 \pm 2.5 \%$, respectively; Jungfraujoch and Niwot Ridge are not significantly different from one another. This new interhemispheric gradient is robust, being consistent amongst the sites measured by three different research groups each with their own methods. It is not an artefact of interlaboratory offsets, since Cape Grim and Jungfraujoch measurements are made by the same group using the same sampling and measurement methods, and the Wellington and Niwot Ridge measurements (measured by different techniques) agree well with the other sites at similar latitude (Cape Grim and Jungfraujoch, respectively). This developing gradient is also apparent in the larger sampling network of Levin et al. (2010) and in a separate $\Delta^{14} \mathrm{CO}_{2}$ sampling network (Graven et al., 2012), although that dataset extends only to 2007.

Graven et al. (2012) demonstrated that increasing (mostly Northern Hemisphere) fossil fuel $\mathrm{CO}_{2}$ emissions cannot explain this $\Delta^{14} \mathrm{CO}_{2}$ interhemispheric gradient, and instead, they postulated that ${ }^{14} \mathrm{C}$ uptake into the Southern Ocean reduced over time. Levin et al. (2010) were able to roughly replicate this interhemispheric gradient in their GRACE model by tuning the terrestrial biosphere fluxes to match the observed global average atmospheric $\mathrm{CO}_{2}$ and $\Delta^{14} \mathrm{CO}_{2}$ records. Where the observations suggest the rapid development of an interhemispheric gradient in the early 2000s (Fig. 5), the GRACE model simulates a more gradual transition over a period of roughly two decades. Independent evidence suggests that the Southern Ocean is more likely to be responsible for this rapid shift in the atmospheric $\Delta{ }^{14} \mathrm{CO}_{2}$ gradient. That is, an apparent reorganization of Southern Ocean carbon exchange in the early 2000s (Landschützer et al., 2015) is postulated to be associated with changes in the upwelling of deep water (DeVries et al., 2017), to which atmospheric $\Delta^{14} \mathrm{CO}_{2}$ is highly sensitive (Rodgers et al., 2011; Graven et al., 2012). The observed $\Delta^{14} \mathrm{CO}_{2}$ interhemispheric gradient is consistent with these postulated changes in upwelling. Other possible explanations for this new interhemispheric $\Delta^{14} \mathrm{CO}_{2}$ gradient are a substantial underreporting of Northern Hemisphere fossil $\mathrm{CO}_{2}$ emissions (e.g. Francey et al., 2013) or changes in the land carbon sink (Wang et al., 2013; Sitch et al., 2015), although this latter is less likely since $\Delta^{14} \mathrm{CO}_{2}$ is much less sensitive to biospheric fluxes than to either ocean or fossil fuel fluxes (e.g. Levin et al., 2010; Turnbull et al., 2009b). Given the limited spatial coverage of the current $\Delta^{14} \mathrm{CO}_{2}$ observing network, it is not possible to robustly determine which of these processes causes the interhemispheric gradient. This could be achieved with more observations of the spatial and temporal variations in atmospheric $\Delta^{14} \mathrm{CO}_{2}$.

\section{Conclusions}

The 60-year-long Wellington $\Delta^{14} \mathrm{CO}_{2}$ record was revised and extended to 2014. Most revisions were minor, but we particularly note that the earlier reported 1990-1993 measurements have been entirely replaced with new measurements. A second period form 1995-2005 has poorer data quality than the rest of the record, and may also be biased high by a few per mil. These data have been revised substantially, and new measurements have been added to this period, but we were unable to definitively identify or correct for bias, so the data have been retained, albeit with caution. We further validated the record by comparison with tree ring samples collected from the Baring Head sampling location and from nearby Eastbourne, Wellington; both tree ring records show excellent agreement with the original record, and indicate that there are no other periods in which the original measurements are problematic.

The Wellington $\Delta^{14} \mathrm{CO}_{2}$ time series records the history of atmospheric nuclear weapons testing and the subsequent decline in $\Delta^{14} \mathrm{CO}_{2}$ as the bomb ${ }^{14} \mathrm{C}$ moved throughout the carbon cycle and ${ }^{14} \mathrm{C}$-free fossil fuel emissions further decreased $\Delta^{14} \mathrm{CO}_{2}$. The timing of the first appearance of the bomb- ${ }^{14} \mathrm{C}$ peak at Wellington is consistent with other recent estimates of interhemispheric exchange time at 1.4 years.

The seasonal cycle at Wellington evolves through the record, apparently dominated by the seasonality of crosstropopause transport, which drives a changing seasonal cycle through time. In the early post-bomb period, the seasonally variable movement of bomb ${ }^{14} \mathrm{C}$ from the northern stratosphere through the northern troposphere to the southern troposphere appears to be the dominant control on the seasonal cycle at Wellington. The seasonal cycle reversed in later years, possibly due to a change in sign of the terrestrial biosphere $\Delta^{14} \mathrm{C}$ signal. In recent years, the seasonal cycle has an amplitude of only $2 \%$, with a maximum in the austral spring. Cape Grim exhibits a similar seasonal cycle magnitude but appears to be very slightly influenced by a terrestrial/anthropogenic signal during the austral winter that is not apparent at Wellington.

During the 1980 s and $1990 \mathrm{~s}, \Delta^{14} \mathrm{CO}_{2}$ was similar at midlatitude clean-air sites in both hemispheres, but since the early 2000s, the Northern Hemisphere $\Delta^{14} \mathrm{CO}_{2}$ has dropped below the Southern Hemisphere by 5-7\%o. The control on this changing interhemispheric gradient cannot be robustly determined from the existing sparse $\Delta^{14} \mathrm{CO}_{2}$ observations but may be due to a change in Southern Ocean dynamics reducing the upwelling of old, ${ }^{14} \mathrm{C}$-poor deep waters, consistent with recent evidence of an increasing Southern Ocean carbon sink. Alternative explanations are an underestimate of Northern Hemisphere fossil fuel $\mathrm{CO}_{2}$ emissions or a changing land carbon sink. This implies that ongoing and expanded Southern Hemisphere $\Delta^{14} \mathrm{CO}_{2}$ observations and modelling may provide a fundamental constraint on our understanding of Southern Ocean dynamics and exchange processes. 
Data availability. The datasets presented in this paper are included as a Supplement. The datasets (including updates as they are available) can be accessed through the World Data Centre for Greenhouse Gases (http://ds.data.jma.go.jp/gmd/wdcgg/) or directly through GNS Science (https://gns.cri.nz/Home/Products/ Databases/Wellington-atmospheric-14CO2-record) or NIWA (ftp: //ftp.niwa.co.nz/tropac/).

\section{The Supplement related to this article is available online at https://doi.org/10.5194/acp-17-14771-2017- supplement.}

Competing interests. The authors declare that they have no conflict of interest.

Acknowledgements. A 60-year-long record takes more than a handful of authors to produce. This work was possible only because of the amazing foresight and scientific understanding of Athol Rafter and Gordon Fergusson, who began this record in the 1950s. Their work was continued over the years by a number of people, including Hugh Melhuish, Martin Manning, Dave Lowe, Rodger Sparks, Charlie McGill, Max Burr and Graeme Lyon. This work was funded by the Government of New Zealand as GNS Science Global Change Through Time core funding and NIWA Greenhouse Gases, Emissions, and Carbon Cycle Science Programme core funding. The authors wish to acknowledge the contribution of New Zealand eScience Infrastructure (NeSI) to the results of this research. New Zealand's national computer and analytics services and team are supported by the NeSI and funded jointly by NeSI's collaborator institutions and through the Ministry of Business, Innovation and Employment (http://www.nesi.org.nz). We thank Scott Lehman (University of Colorado) and Ingeborg Levin (University of Heidelberg) for sharing their $\Delta^{14} \mathrm{CO}_{2}$ datasets for comparison with the Wellington record.

Edited by: Neil Harris

Reviewed by: Samuel Hammer, John Miller, and

one anonymous referee

\section{References}

AECOM New Zealand Limited: Community greenhouse gas inventory for Wellington City and the Greater Wellington Region 2000-2015, Wellington, 2016.

Australian Government: State and territory greenhouse gas inventories 2014, Department of the Environment, 2016.

Baisden, W. T., Prior, C. A., Chambers, D., Canessa, S., Phillips, A., Bertrand, C., Zondervan, A., and Turnbull, J. C.: Radiocarbon sample preparation and data flow at Rafter: Accommodating enhanced throughput and precision, Nucl. Instrum. Meth. B, 294, 194-198, 2013.

Bevington, P. R. and Robinson, D. K.: Data reduction and error analysis for the physical sciences, 3rd Edn., McGraw-Hill, 2003.
Boden, T. A., Marland, G., and Andres, R. J.: Global, Regional, and National Fossil-Fuel $\mathrm{CO}_{2}$ Emissions, Carbon Dioxide Information Analysis Center, Oak Ridge National Laboratory, U.S. Department of Energy, Oak Ridge, Tenn., USA, 2017.

Bozhinova, D., Combe, M., Palstra, S. W. L., Meijer, H. A. J., Krol, M. C., and Peters, W.: The importance of crop growth modeling to interpret the ${ }^{14} \mathrm{CO}_{2}$ signature of annual plants, Global Biogeochem. Cy., 27, 792-803, 2013.

Brailsford, G. W., Stephens, B. B., Gomez, A. J., Riedel, K., Mikaloff Fletcher, S. E., Nichol, S. E., and Manning, M. R.: Long-term continuous atmospheric $\mathrm{CO}_{2}$ measurements at Baring Head, New Zealand, Atmos. Meas. Tech., 5, 3109-3117, https://doi.org/10.5194/amt-5-3109-2012, 2012.

Broecker, W. S., Peng, T.-H., Ostlund, H., and Stuiver, M.: The distribution of bomb radiocarbon in the ocean, J. Geophys. Res., C4, 6953-6970, 1985.

Caldeira, K., Rau, G. H., and Duffy, P. B.: Predicted net efflux of radiocarbon from the ocean and increase in atmospheric radiocarbon content, Geophys. Res. Lett., 25, 3811-3814, 1998.

Currie, K. I., Brailsford, G., Nichol, S., Gomez, A., Sparks, R., Lassey, K. R., and Riedel, K.: Tropospheric ${ }^{14} \mathrm{CO}_{2}$ at Wellington, New Zealand: the world's longest record, Biogeochemistry, 104, 5-22, 2011.

DeVries, T., Holzer, M., and Primeau, F.: Recent increase in oceanic carbon uptake driven by weaker upper-ocean overturning, Nature, 542, 215-218, 2017.

Djuricin, S., Pataki, D. E., and Xu, X.: A comparison of tracer methods for quantifying $\mathrm{CO}_{2}$ sources in an urban region, J. Geophys. Res., 115, https://doi.org/10.1029/2009jd012236, 2010.

Enting, I. G.: Nuclear weapons data for use in carbon cycle modelling, CSIRO Division of Atmospheric Physics and Technology, Melbourne, Australia, 1982.

Ferretti, D. F., Lowe, D. C., Martin, R. H., and Brailsford, G. W.: A new gas chromatograph-isotope ratio mass spectrometry technique for high-precision, $\mathrm{N}_{2} \mathrm{O}$-free analysis of $\delta^{13} \mathrm{C}$ and $\delta^{18} \mathrm{O}$ in atmospheric $\mathrm{CO}_{2}$ from small air samples. J. Geophys. Res.Atmos., 105, 6709-6718, 2000.

Francey, R. J., Trudinger, C. M., van der Schoot, M., Law, R. M., Krummel, P. B., Langenfelds, R. L., Steele, L. P., Allison, C. E., Stavert, A. R., Andres, R. J., and Rödenbeck, C.: Atmospheric verification of anthropogenic $\mathrm{CO}_{2}$ emission trends, Nature Climate Change 3, 520-524, 2013.

Geller, L. S., Elkins, J. W., Lobert, J. M., Clarke, A. D., Hurst, D. F., Butler, J. H., and Myers, R. C.: Tropospheric SF 6 : Observed latitudinal distribution and trends, derived emissions and interhemispheric exchange time, Geophys. Res. Lett., 24, 675-678, 1997.

Graven, H. D. and Gruber, N.: Continental-scale enrichment of atmospheric ${ }^{14} \mathrm{CO}_{2}$ from the nuclear power industry: potential impact on the estimation of fossil fuel-derived $\mathrm{CO}_{2}$, Atmos. Chem. Phys., 11, 12339-12349, https://doi.org/10.5194/acp-11-123392011, 2011.

Graven, H. D., Guilderson, T. P., and Keeling, R. F.: Observations of radiocarbon in $\mathrm{CO}_{2}$ at seven global sampling sites in the Scripps flask network: Analysis of spatial gradients and seasonal cycles, J. Geophys. Res., 117, https://doi.org/10.1029/2011jd016535, 2012.

Hogg, A. G.: SHCAL13 Southern Hemisphere calibration, 050000 years CAL BP, Radiocarbon, 2013. 
Hua, Q., Barbetti, M., Jacobsen, G., Zoppi, U., and Lawson, E.: Bomb radiocarbon in annual tree rings from Thailand and Australia, Nucl. Instrum. Meth. B, 172, 359-365, 2000.

Hua, Q., Barbetti, M., and Rakowski, A. Z.: Atmospheric radiocarbon for the period 1950-2010, Radiocarbon, 55, 1-14, 2013.

Kanu, A., Comfort, L., Guilderson, T. P., Cameron-Smith, P. J., Bergmann, D. J., Atlas, E. L., Schauffler, S., and Boering, K. A.: Measurements and modelling of contemporary radiocarbon in the stratosphere, Geophys. Res. Lett., 43, https://doi.org/10.1002/2015GL066921, 2015.

Keeling, C. D.: The concentration and isotopic abundances of carbon dioxide in rural and marine air, Geochim. Cosmochim. Ac., 24, 277-298, 1961

Keeling, C. D. and Whorf, T.: Atmospheric $\mathrm{CO}_{2}$ records from sites in the SIO air sampling network, Trends: A compendium of data of global change, Carbon Dioxide Information Analysis Center, Oak Ridge National Laboratory, Oak Ridge, Tenn., USA, 2005.

Keeling, C. D., Piper, S. C., Bacastow, R. B., Wahlen, M., Whorf, T. P., Heimann, M., and Meijer, H. A. J.: Exchanges of atmospheric $\mathrm{CO}_{2}$ and ${ }^{13} \mathrm{CO}_{2}$ with the terrestrial biosphere and oceans from 1978 to 2000. I. Global aspects, SIO Reference Series, Scripps Institution of Oceanography, San Diego, 88 pp., 2001.

Keeling, C. D., Piper, S. C., Whorf, T. P., and Keeling, R. F.: Evolution of natural and anthropogenic fluxes of atmospheric $\mathrm{CO}_{2}$ from 1957 to 2003, Tellus B, 63, 1-22, 2011.

Key, R. M.: A global ocean carbon climatology: Results from Global Data Analysis Project (GLODAP), Global Biogeochem. Cy., 18, https://doi.org/10.1029/2004gb002247, 2004.

Kjellström, E., Feichter, J., and Hoffman, G.: Transport of $\mathrm{SF}_{6}$ and ${ }^{14} \mathrm{CO}_{2}$ in the atmospheric general circulation model ECHAM4, Tellus B, 52, 1-18, 2000.

Landschützer, P., Gruber, N., Haumann, F. A., Rödenbeck, C., Bakker, D. C. E., van Heuven, S., Hoppema, M., Metzl, N., Sweeney, C., Takahashi, T., Tilbrook, B., and Wanninkhof, R.: The reinvigoration of the Southern Ocean carbon sink, Science, 349, 1221-1224, 2015.

Law, R. M., Steele, L. P., Krummel, P. B., and Zahorowski, W.: Synoptic variations in atmospheric $\mathrm{CO}_{2}$ at Cape Grim: a model intercomparison, Tellus B, 62, 810-820, 2010.

Lehman, S. J., Miller, J. B., Wolak, C., Southon, J. R., Tans, P. P., Montzka, S. A., Sweeney, C., Andrews, A. E., LaFranchi, B. W., Guilderson, T. P., and Turnbull, J. C.: Allocation of terrestrial carbon sources using ${ }^{14} \mathrm{CO}_{2}$ : Methods, measurement, and modelling, Radiocarbon, 55, 1484-1495, 2013.

Levin, I., Kromer, B., Schoch-Fischer, H., Bruns, M., Munnich, M., Berdau, D., Vogel, J. C., and Munnich, K. O.: 25 years of tropospheric ${ }^{14} \mathrm{C}$ observations in central Europe, Radiocarbon 27 , 1-19, 1985.

Levin, I., Kromer, B., Schmidt, M., and Sartorius, H.: A novel approach for independent budgeting of fossil fuel $\mathrm{CO}_{2}$ over Europe by ${ }^{14} \mathrm{CO}_{2}$ observations, Geophys. Res. Lett., 30, 2194, https://doi.org/10.1029/2003gl018477, 2003.

Levin, I., Naegler, T., Kromer, B., Diehl, M., Francey, R. J., GomezPelaez, A. J., Steele, L. P., Wagenbach, D., Weller, R., and Worthy, D. E.: Observations and modelling of the global distribution and long-term trend of atmospheric ${ }^{14} \mathrm{CO}_{2}$, Tellus B, 62, 26-46, 2010.
Levin, I., Kromer, B., and Hammer, S.: Atmospheric $\Delta^{14} \mathrm{CO}_{2}$ trend in Western European background air from 2000 to 2012, Tellus B, 65, https://doi.org/10.3402/tellusb.v65i0.20092, 2013.

Lopez, M., Schmidt, M., Delmotte, M., Colomb, A., Gros, V., Janssen, C., Lehman, S. J., Mondelain, D., Perrussel, O., Ramonet, M., Xueref-Remy, I., and Bousquet, P.: $\mathrm{CO}, \mathrm{NO}_{\mathrm{x}}$ and ${ }^{13} \mathrm{CO}_{2}$ as tracers for fossil fuel $\mathrm{CO}_{2}$ : results from a pilot study in Paris during winter 2010, Atmos. Chem. Phys., 13, 7343-7358, https://doi.org/10.5194/acp-13-7343-2013, 2013.

Lowe, D. C.: Atmospheric carbon dioxide in the Southern Hemisphere, J. Clean Air Soc. Aust. NZ, 8, 12-15, 1974.

Lowe, D. C. and Judd, W.: Graphite target preparation for radiocarbon dating by accelerator mass spectrometry, Nucl. Instrum. Meth. B, 28, 113-116, 1987.

Manning, M. R., Lowe, D. C., Melhuish, W. H., Sparks, R. J., Wallace, G., Brenninkmeijer, C. A. M., and McGill, R. C.: The use of radiocarbon measurements in atmospheric sciences, Radiocarbon, 32, 37-58, 1990.

Meijer, H. A. J., Smid, H. M., Perez, E., and Keizer, M. G.: Isotopic characterization of anthropogenic $\mathrm{CO}_{2}$ emissions using isotopic and radiocarbon analysis, Phys. Chem. Earth 21, 483-487, 1996.

Meijer, H. A. J., Pertuisot, M.-H., and van der Plicht, J.: High accuracy ${ }^{14} \mathrm{C}$ measurements for atmospheric $\mathrm{CO}_{2}$ samples by AMS, Radiocarbon, 48, 355-372, 2006.

Miller, J. B., Lehman, S. J., Montzka, S. A., Sweeney, C., Miller, B. R., Wolak, C., Dlugokencky, E. J., Southon, J. R., Turnbull, J. C., and Tans, P. P.: Linking emissions of fossil fuel $\mathrm{CO}_{2}$ and other anthropogenic trace gases using atmospheric ${ }^{14} \mathrm{CO}_{2}$, J. Geophys. Res., 117, D08302, https://doi.org/10.1029/2011JD017048, 2012.

Naegler, T. and Levin, I.: Observation-based global biospheric excess radiocarbon inventory 1963-2005, J. Geophys. Res., 114, https://doi.org/10.1029/2008jd011100, 2009.

Naegler, T., Ciais, P., Rodgers, K., and Levin, I.: Excess radiocarbon constraints on air-sea gas exchange and the uptake of $\mathrm{CO}_{2}$ by the oceans, Geophys. Res. Lett., 33, https://doi.org/10.1029/2005gl025408, 2006.

Norris, M. W.: Reconstruction of historic fossil $\mathrm{CO}_{2}$ emissions using radiocarbon measurements from tree rings, School of Geography, Environment and Earth Sciences, Victoria University of Wellington, 2015.

Nydal, R. and Lövseth, K.: Tracing bomb ${ }^{14} \mathrm{C}$ in the atmosphere 1962-1980, J. Geophys. Res., 88, 3621-3642, 1983.

Oeschger, H., Siegenthaler, U., Schotterer, U., and Gugelmann, A.: A box diffusion model to study the carbon dioxide exchange in nature, Tellus XXVII, 168-192, 1975.

Otago Daily Times: Polar ice caps may melt with industrialisation, Otago Daily Times, 23/1/1957 Edn., Dunedin, New Zealand, 1, 1957.

Patra, P. K., Houweling, S., Krol, M., Bousquet, P., Belikov, D., Bergmann, D., Bian, H., Cameron-Smith, P., Chipperfield, M. P., Corbin, K., Fortems-Cheiney, A., Fraser, A., Gloor, E., Hess, P., Ito, A., Kawa, S. R., Law, R. M., Loh, Z., Maksyutov, S., Meng, L., Palmer, P. I., Prinn, R. G., Rigby, M., Saito, R., and Wilson, C.: TransCom model simulations of $\mathrm{CH}_{4}$ and related species: linking transport, surface flux and chemical loss with $\mathrm{CH}_{4}$ variability in the troposphere and lower stratosphere, Atmos. Chem. Phys., 11, 12813-12837, https://doi.org/10.5194/acp-11-128132011, 2011. 
Rafter, T. A.: ${ }^{14} \mathrm{C}$ variations in nature and the effect on radiocarbon dating, New Zealand Journal of Science and Technology, B37, 363-370, 1955.

Rafter, T. A. and Fergusson, G.: Atmospheric radiocarbon as a tracer in geophysical circulation problems, United Nations Peaceful Uses of Atomic Energy, Pergamon Press, London, 1959.

Randerson, J. T., Enting, I. G., Schuur, E. A. G., Caldeira, K., and Fung, I. Y.: Seasonal and latitudinal variability of troposphere $\Delta^{14} \mathrm{CO}_{2}$ : Post bomb contributions from fossil fuels, oceans, the stratosphere, and the terrestrial biosphere, Global Biogeochem. Cy., 16, 1112, https://doi.org/10.1029/2002gb001876, 2002.

Reimer, P. J., Brown, T. A., and Reimer, R. W.: Discussion: Reporting and calibration of post-bomb ${ }^{14} \mathrm{C}$ data, Radiocarbon, 46 , 1299-1304, 2004.

Rodgers, K. B., Mikaloff-Fletcher, S. E., Bianchi, D., Beaulieu, C., Galbraith, E. D., Gnanadesikan, A., Hogg, A. G., Iudicone, D., Lintner, B. R., Naegler, T., Reimer, P. J., Sarmiento, J. L., and Slater, R. D.: Interhemispheric gradient of atmospheric radiocarbon reveals natural variability of Southern Ocean winds, Clim. Past, 7, 1123-1138, https://doi.org/10.5194/cp-71123-2011, 2011.

Sitch, S., Friedlingstein, P., Gruber, N., Jones, S. D., MurrayTortarolo, G., Ahlström, A., Doney, S. C., Graven, H., Heinze, C., H untingford, C., Levis, S., Levy, P. E., Lomas, M., Poulter, B., Viovy, N., Zaehle, S., Zeng, N., Arneth, A., Bonan, G., Bopp, L., Canadell, J. G., Chevallier, F., Ciais, P., Ellis, R., Gloor, M., Peylin, P., Piao, S. L., Le Quéré, C., Smith, B., Zhu, Z., and Myneni, R.: Recent trends and drivers of regional sources and sinks of carbon dioxide, Biogeosciences, 12, 653679, https://doi.org/10.5194/bg-12-653-2015, 2015.

Steinkamp, K., Mikaloff Fletcher, S. E., Brailsford, G., Smale, D., Moore, S., Keller, E. D., Baisden, W. T., Mukai, H., and Stephens, B. B.: Atmospheric $\mathrm{CO}_{2}$ observations and models suggest strong carbon uptake by forests in New Zealand, Atmos. Chem. Phys., 17, 47-76, https://doi.org/10.5194/acp-17-472017, 2017.

Stephens, B. B., Brailsford, G. W., Gomez, A. J., Riedel, K., Mikaloff Fletcher, S. E., Nichol, S., and Manning, M.: Analysis of a 39-year continuous atmospheric $\mathrm{CO} 2$ record from Baring Head, New Zealand, Biogeosciences, 10, 2683-2697, https://doi.org/10.5194/bg-10-2683-2013, 2013.

Stuiver, M. and Polach, H. A.: Discussion: Reporting of ${ }^{14} \mathrm{C}$ data, Radiocarbon, 19, 355-363, 1977.

Stuiver, M. and Quay, P. D.: Atmospheric 14C changes resulting from fossil fuel $\mathrm{CO}_{2}$ release and cosmic ray flux variability, Earth Planet. Sc. Lett., 53, 349-362, 1981.

Suess, H. E.: Radiocarbon concentration in modern wood, Science, 122, 414-417, 1955.

Sweeney, C., Gloor, E., Jacobson, A. R., Key, R. M., McKinley, G., Sarmiento, J. L., and Wanninkhof, R.: Constraining global air-sea gas exchange for $\mathrm{CO}_{2}$ with recent bomb ${ }^{14} \mathrm{C}$ measurements, Global Biogeochem. Cy., 21, https://doi.org/10.1029/2006gb002784, 2007.

Tans, P. P., De Jong, A. F., and Mook, W. G.: Natural atmospheric ${ }^{14} \mathrm{C}$ variation and the Suess effect, Nature, 280, 826-828, 1979.
Thoning, K. W., Tans, P. P., and Komhyr, W. D.: Atmospheric carbon dioxide at Mauna Loa Observatory 2, Analysis of the NOAA GMCC data, 1974-1985, J. Geophys. Res., 94, 85498563, 1989.

Trumbore, S. E.: Age of soil organic matter and soil respiration: Radiocarbon constraints on belowground $\mathrm{C}$ dynamics, Ecol. Appl., 10, 399-411, 2000.

Turnbull, J. C.: Development of a high precision ${ }^{14} \mathrm{CO}_{2}$ measurement capability and application to carbon cycle studies, Geological Sciences, University of Colorado, Boulder, 132 pp., 2006.

Turnbull, J. C., Lehman, S. J., Miller, J. B., Sparks, R. J., Southon, J. R., and Tans, P. P.: A new high precision ${ }^{14} \mathrm{CO}_{2}$ time series for North American continental air, J. Geophys. Res., 112, D11310, 2007.

Turnbull, J. C., Miller, J. B., Lehman, S. J., Hurst, D., Peters, W., Tans, P. P., Southon, J., Montzka, S. A., Elkins, J. W., Mondeel, D. J., Romashkin, P. A., Elansky, N., and Skorokhod, A.: Spatial distribution of $\Delta^{14} \mathrm{CO}_{2}$ across Eurasia: measurements from the TROICA-8 expedition, Atmos. Chem. Phys., 9, 175187, https://doi.org/10.5194/acp-9-175-2009, 2009a.

Turnbull, J. C., Rayner, P. J., Miller, J. B., Naegler, T., Ciais, P., and Cozic, A.: On the use of ${ }^{14} \mathrm{CO}_{2}$ as a tracer for fossil fuel $\mathrm{CO}_{2}$ : quantifying uncertainties using an atmospheric transport model, J. Geophys. Res., 114, D22302, https://doi.org/10.1029/2009JD012308, 2009b.

Turnbull, J. C., Sweeney, C., Karion, A., Newberger, T., Lehman, S. J., Tans, P. P., Davis, K.J ., Lauvaux, T., Miles, N. L., Richardson, S. J., Cambaliza, M. O., Shepson, P. B., Gurney, K., Patarasuk, R., and Razlivanov, I.: Toward quantification and source sector identification of fossil fuel $\mathrm{CO}_{2}$ emissions from an urban area: Results from the INFLUX experiment, J. Geophys. Res.-Atmos., https://doi.org/10.1002/2014jd022555, 2015a.

Turnbull, J. C., Zondervan, A., Kaiser, J., Norris, M., Dahl, J., Baisden, W. T., and Lehman, S. J.: High-precision atmospheric ${ }^{14} \mathrm{CO}_{2}$ measurement at the Rafter Radiocarbon Laboratory, Radiocarbon, 57, 377-388, 2015b.

Wang, Y., Li, M., and Shen, L.: Accelerating carbon uptake in the Northern Hemisphere: evidence from the interhemispheric difference of atmospheric $\mathrm{CO}_{2}$ concentrations, Tellus $\mathrm{B}, 65$, https://doi.org/10.3402/tellusb.v65i0.20334, 2013.

Ziehn, T., Nickless, A., Rayner, P. J., Law, R. M., Roff, G., and Fraser, P.: Greenhouse gas network design using backward Lagrangian particle dispersion modelling - Part 1: Methodology and Australian test case, Atmos. Chem. Phys., 14, 9363-9378, https://doi.org/10.5194/acp-14-9363-2014, 2014.

Zondervan, A. and Sparks, R. J.: Development plans for the AMS facility at the Institute of Geological and Nuclear Sciences, New Zealand, Radiocarbon, 38, 133-134, 1996.

Zondervan, A., Hauser, T., Kaiser, J., Kitchen, R., Turnbull, J. C., and West, J. G.: XCAMS: The compact ${ }^{14} \mathrm{C}$ accelerator mass spectrometer extended for 10Be and 26Al at GNS Science, New Zealand, Nucl. Instrum. Meth. B, 361, 25-33, 2015. 